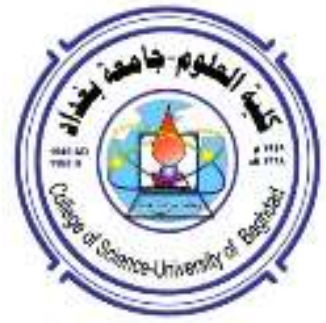

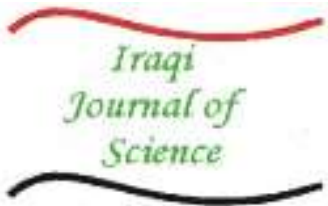

ISSN: 0067-2904

\title{
Degradable Evaluation of Two Types of Biopolymers in Loam Soil
}

\author{
Leqaa M. Hussain $^{1^{*}}$, Salma M. Hassan ${ }^{2}$, M. Hassan S. Bahia ${ }^{3}$
}

${ }^{1,2}$ University of Baghdad, College of Science, Department of physics, Baghdad, Iraq

${ }^{3}$ Universities of Baghdad, Coll. of Agric. Eng. Sci, Department of Soil Sci. and Water Resources, Baghdad, Iraq

Received: 2/9/2019 Accepted: 17/12/2019

\begin{abstract}
Gel-biopolymers were prepared by different weights of two polymers (PVA, and PEG) dissolved with distilled water. Thick films of these polymers were prepared by using the casting method, with different thicknesses $(\mathrm{t}=0.48,0.34 \mathrm{~mm}$ for PVA and $\mathrm{t}=0.58 \mathrm{~mm}$ for PEG). The objective of this research is to determine the viability of the organic polymer films of PEG and PVA on decomposition and the time required for their degradation in the soil. The purpose is to use these polymers in industry without leaving plastic residues along with the possibility of their application as fertilizers for soil. The results showed that PEG film was degraded during the first week, while PVA film was changed in weight from 0.3 to $0.23 \mathrm{~g}$ and thickness from 0.34 to $0.21 \mathrm{~cm}$. We also observed change in the shape of the sample along with ripples and holes during three month.
\end{abstract}

Keywords: Polyvinyl alcohol, polyethylene glycol, soil fertilizer, Biodegradable, Microbiology.

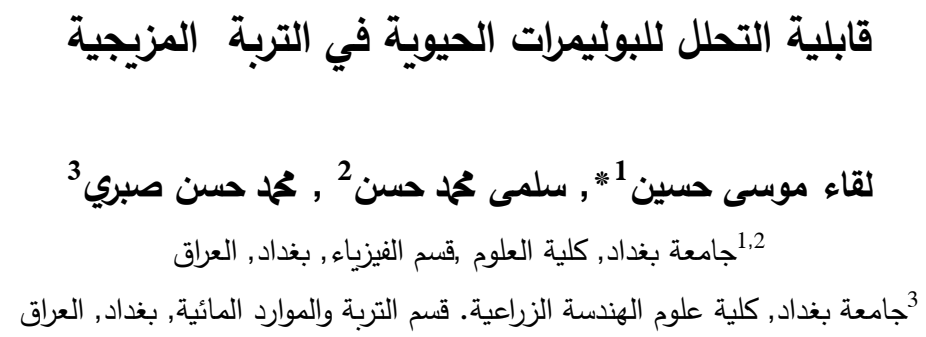

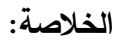

تم تحضير البوليمرات الهلامية بوزن مختلف من اثثين من البوليمرات (بولي ايثلين جلايكول، بولي فينيل

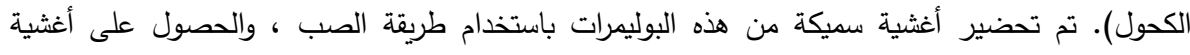

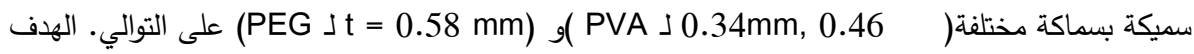

من هذا البحث هو تحديد مدى صلاحية فيلم البوليمر العضويPPVA ع عند التحلل والوقت اللازم لتدهوره

في التربة لاستخدامه في الصناعة ودون ترك بقايا بلاستيكية وإمكانية استخدام هذه البوليمرات كسماد للتربة ،

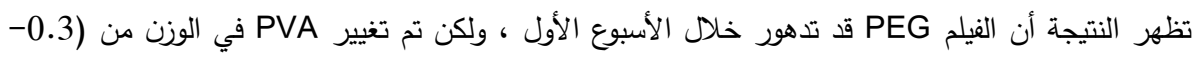

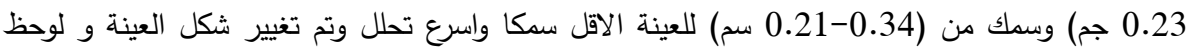

\section{Introduction}

حدوث تموج وثقوب خلال ثلاثة أشهر . من من

Polymer is a very important class of materials which is applied in our daily life in the forms of rubber, plastic and resins [1]. A growing interest has been shown on biodegradable polymers such as polyvinyl alcohol and polyethylene glycol which consist of a chain of monomers that have the 
potential to degrade into raw materials of importance as soil conditioners . This decomposition produces water, carbon and other organic matter and is very safe, non-toxic, an, non-carcinogenic [2, 3]. Polymeric soil conditioners have been known since the 1950 [4]. The productivity of soil is often dependent on its physical properties, because of its different water-holding and deep percolation capacities which affect the efficiency of water and fertilizer used by plants [5]. Gel-polymers were developed to enhance the physical properties of soil by increasing water-holding capacity, water use efficiency, permeability, and infiltration rates, while reducing compaction tendency and stopping erosion and water run-off.

There are many studies concerning soil treatment and improvement of the physical properties of soil by using biopolymers or synthetic polymers; for example, Ozdmira et al. (2015 used different organic and inorganic amendments to reduce soil erodibility and amend its properties [6]. Obasi et al. (2013) studied the effects of potato starch on the mechanical properties and bio-degradability of polypropylene using the soil burial test method. The results showed that the tensile properties for both PP polypropylenes and polypropylenes potato starch PPS were decreased with increasing starch content and burial period. Potato starch-filled polypropylenes were degraded by loss of structural integrity, which renders them advantageous in terms of environmental protection [7]. The aim of the present research is to produce degradable polymers that provide advantageous properties to soil.

\section{Experimental Procedure and Raw materials}

The raw materials used in this research are listed in Table -1 which shows the materials with their specifications and the supplying companies.

Table 1-The raw materials used in the study along with their properties and suppliers.

\begin{tabular}{|c|c|c|}
\hline Material & Properties & Origin \\
\hline Poly-ethylene glycol & $\begin{array}{c}\text { PEG molecular weight: } 1900 \text { to } \\
2200\end{array}$ & $\begin{array}{c}\text { Organics BDH chemical Ltd } \\
\text { Poole England }\end{array}$ \\
\hline Poly-vinyl alcohol & PVA purity 99.9\% & Himedia-india \\
\hline Loam soil & Calcareous soil & Middle of Iraq \\
\hline
\end{tabular}

The thick films were prepared by dissolving biodegradable polymers (PVA, PEG) in distilled water. A viscous solution of PVA or PEG was prepared by dissolving $1 \mathrm{~g}$ of the polymer in $4 \mathrm{ml}$ of distilled water. The glass substrates were cleaned thoroughly using ethyl alcohol and distilled water, and the viscous solution was poured into them. The sample of PVA was dried in an electrical oven at $40{ }^{\circ} \mathrm{C}$ for 5 hours, whereas PEG was dried in room temperature. The samples had different thicknesses which were measured using a digital micrometer. The thickness of the films was estimated to be $\mathrm{t}=0.46$ and $0.34 \mathrm{~cm}$ for PVA and $0.58 \mathrm{~cm}$ for PEG. Loam soil was taken from central Iraq (Baghdad). A quantity of loam soil was taken in beakers and crushed and sieved to $2 \mathrm{~mm}$ to remove the gravels. Soil field capacity was calculated by preventing evaporation of water through covering with nylon and measuring the weight for 3 days in a row until proven weight. Field capacity was 0.33 $\%$. Soil organic matter content was calculated using wet oxidation according to Walkley and Black method, as described by Jackson in $1958[8,9]$. Soil carbon content was $0.245 \mathrm{mg} / \mathrm{kg}$. The test was carried out over a period of 2 weeks. Thick films of bio-polymers were buried into the soil while maintaining field capacity by adding water. Weight was determined every week for 3 month. All of the film samples were buried in the pot under $5 \mathrm{~cm}$ of soil, while the temperature was $15-30{ }^{\circ} \mathrm{C}$. The test was carried out in the material laboratory over a period of 90 days ( 3 months) from January to April 2019. Samples were collected from the pot, gently cleaned by water, dried, and weighed. The percentage weight loss of the samples was calculated, along with the change in dimensions. Fourier transform infrared (FTIR) spectroscopy was conducted for the soil and for the samples before and after being buried in soil and the results were compared.

\section{Results and Discussion FTIR Spectroscopy}

Figure-(1, shows the FTIR chart for loam soil, from which two absorption bands can be noticed which indicate the hydrophobic ( $\mathrm{CH}-)$, and the hydrophilic (CO-) functional groups. The $\mathrm{C}-\mathrm{H}$ bands occurred at the $3200-3600 / \mathrm{cm}$, while the C-O wide bands occurred at 1000-1500/cm. Our result agree with those reported earlier by another group [10]. 


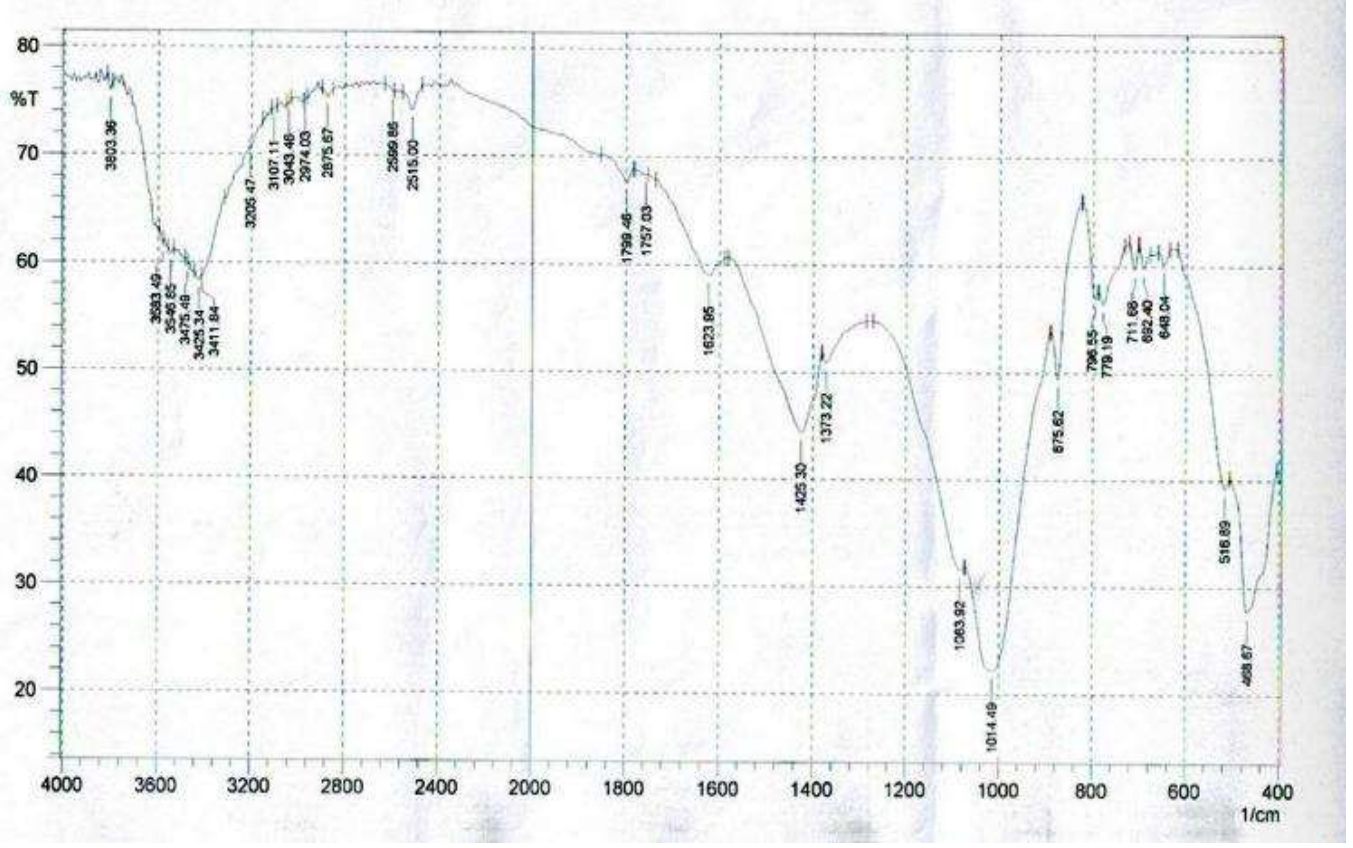

Figure 1- The FTIR chart for loam soil

Figure-2 shows the characteristic bands of FTIR for PVA thick film before being buried in soil. A strong characteristic peak is assigned for the stretching vibration mode of $\mathrm{O}-\mathrm{H}$ group at $3371.68 \mathrm{~cm}^{-1}$. The absorption peak at (1516) $\mathrm{cm}^{-1}$ is assigned for PVA, whereas the peaks at (1429) and (1093) $\mathrm{cm}^{-1}$ are attributed to $\mathrm{C}-\mathrm{H}$ and $\mathrm{C}-\mathrm{O}$ bending bonds, respectively. The absorption peak at $(3570) \mathrm{cm}^{-1}$ is assigned to the hydrogen bond due to the hydrophilic forces (intermolecular, and intra molecular hydrogen bond). The absorption peak at (1140) $\mathrm{cm}^{-1}$ corresponds to the $\mathrm{C}-\mathrm{C}$ symmetric stretching for PVA. These results are in agreement with those previously reported [10-11].

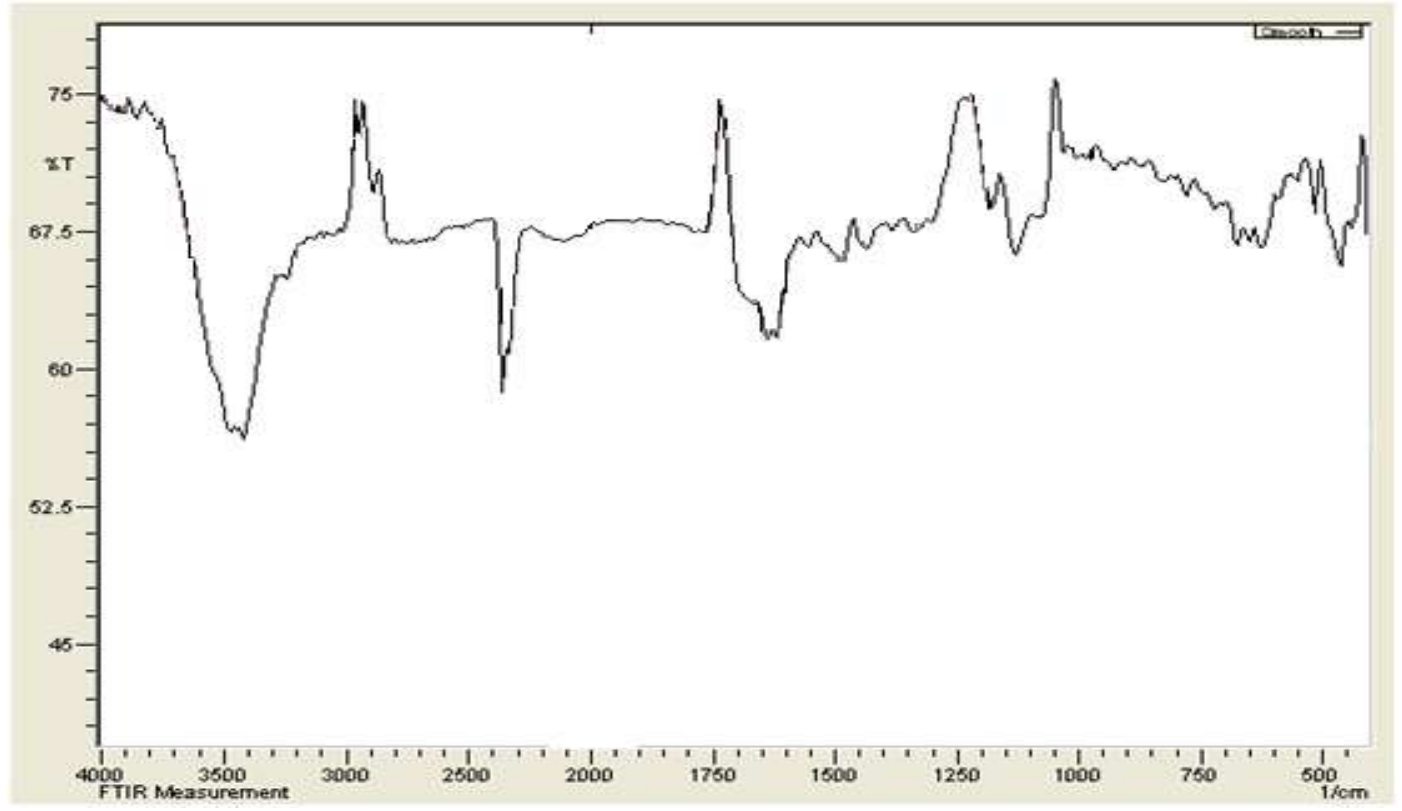

Figure 2- FTIR results for PVA before being buried in soil.

Figure-3 shows FTIR patterns for PVA after being buried in the soil. It is noticed that the intensity of the peak of absorption band was increased because of the interaction between the particles of loam soil with the PVA sample, especially in the hydrophilic and hydrophobic groups. The most absorption peaks are listed in Table-2. 


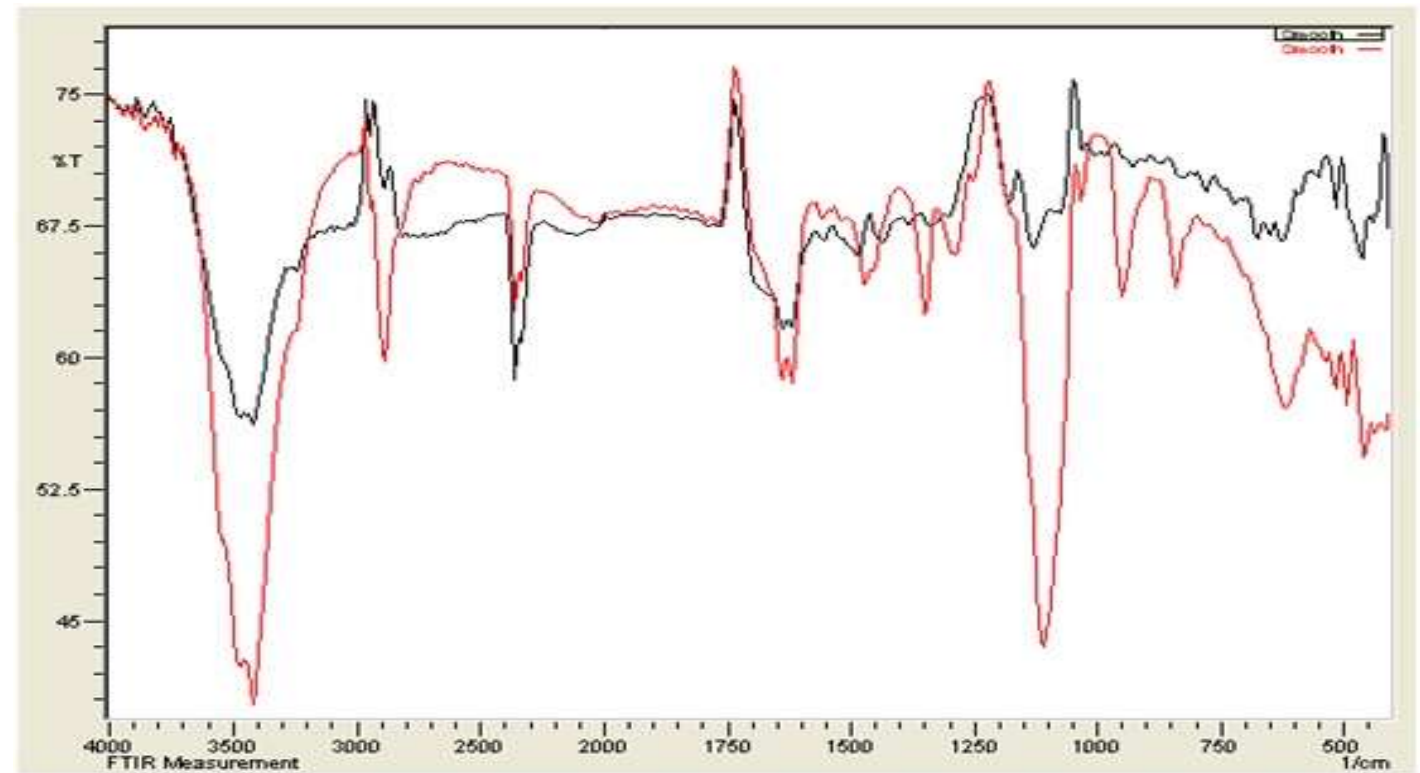

Figure 3-FTIR patterns for PVA after being buried in soil.

Table 2-A list of the observed peaks of PVA after being buried in soil

\begin{tabular}{|c|c|c|}
\hline Peak cm & Assignment & Characterization \\
\hline$(840-984)$ & H-C & Rocking \\
\hline$(1033-1111)$ & $\begin{array}{l}\text { C-O-C } \\
\text { H-O-C }\end{array}$ & Stretching \\
\hline$(1284-1350)$ & H-C & Wagging \\
\hline$(1454-1558)$ & H-C-H & Bend of CH2 \\
\hline$(1620-1639)$ & H-O & Bend of OH \\
\hline$(1745)$ & C=O & Stretching \\
\hline$(1713)$ & C=O & $\begin{array}{c}\text { Characteristics carbonyl } \\
\text { vibration in the residual } \\
\text { acetate in PVA }\end{array}$ \\
\hline$(2746-2943)$ & H-C & Stretching \\
\hline$(3414-3464)$ & H--O & Stretching \\
\hline
\end{tabular}




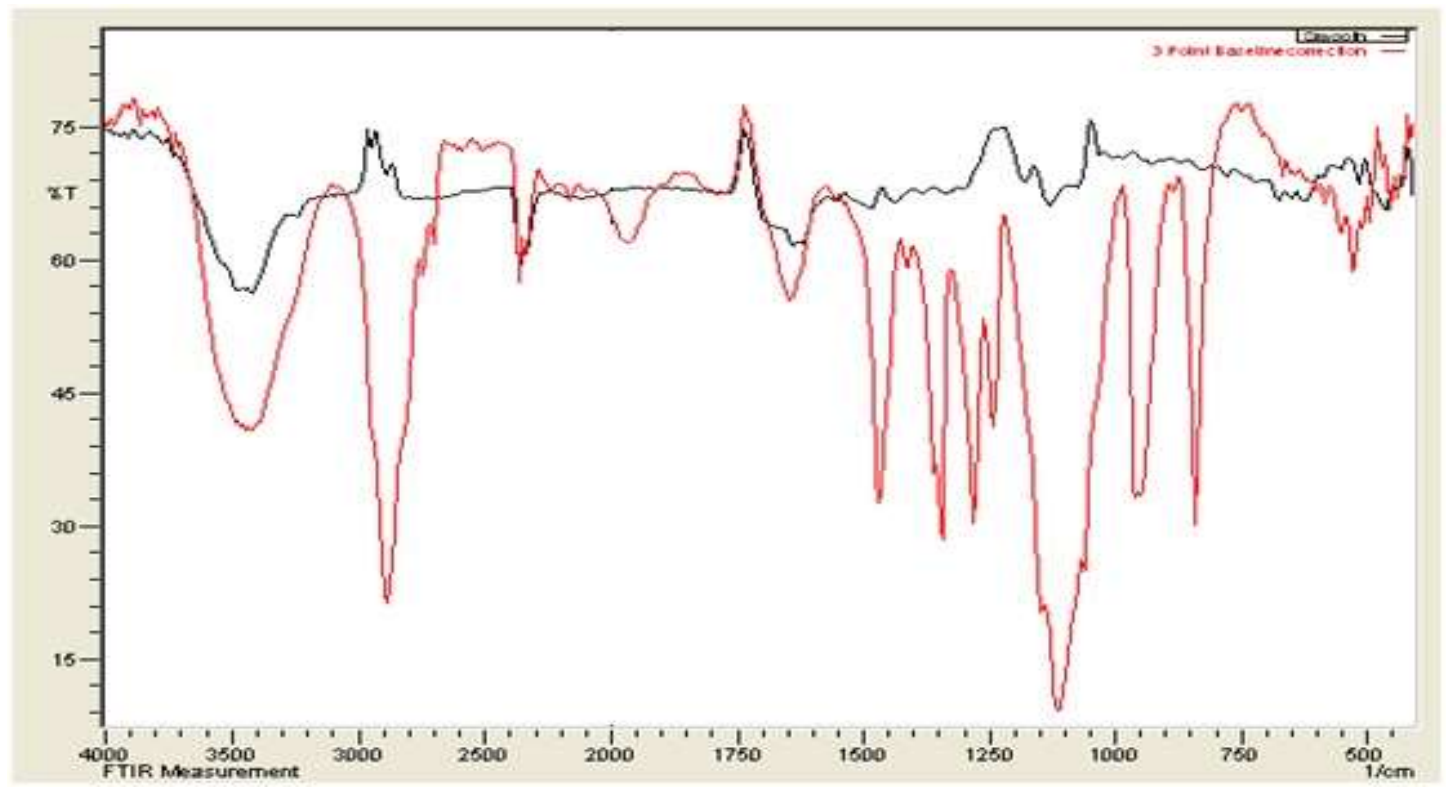

Figure 4-FTIR patterns for PEG before and after being buried in loam soil.

Figure-4 shows FTIR patterns for PEG polymer which revealed the same characteristic peaks as those for PVA; it has $(\mathrm{C}-\mathrm{C})$ stretched, $(\mathrm{C}-\mathrm{O})$ stretched, and $(\mathrm{C}-\mathrm{H})$ bending for methylene group along with $\mathrm{O}-\mathrm{H}$ stretching, while vibration is observed in the region of $3478 \mathrm{~cm}^{-1}$ [12].

\section{Bio-degradability}

Micro organic test

The two biopolymer films behaved similarly in the micro organic culture test through our primary experiments. Soil microbial quantities are presented in Table-3, which shows that the number of microbes was increased. The bacteria were richest using polymer films and fungi were richer using PEG film. The covering of films could produce more microbial growth which can be caused by the degradation of the film generated. The increase in bacteria and fungi might be beneficial for the degradation of this polymer film. The microbiological analysis shows the percentage of bacteria and fungi. They were found to be optically transparent to visible light and mechanically stable to be handled. The microbial quantities are presented and show that the number of microbes was increased over time, as shown in Table-3.

Table 3- The results of microbiological tests

\begin{tabular}{|c|c|c|c|}
\hline Sample & Bactria test & Fungi test & Carbon test mg/kg \\
\hline Loam soil & $1.5^{*} 10^{6}$ & $0.6^{*} 10^{4}$ & 0.245 \\
\hline PEG & $4.5^{*} 10^{6}$ & $3.2^{*} 10^{4}$ & 0.38 \\
\hline PVA & $4 * 10^{6}$ & $3 * 10^{4}$ & 0.36 \\
\hline
\end{tabular}

The number of bacteria in the soil and their activity increases if fertility is available. In $1 \mathrm{~cm}^{3}$ of fertile soil, there were 6-10 million units, while in $1 \mathrm{~cm}^{3}$ of weak soil, the number of bacteria was not higher than 450 thousand units. The largest number of bacteria was found in the soil at a depth of 22$30 \mathrm{~cm}$ where appropriate conditions are available; the greater the depth in the soil the less the number of bacteria. The bacteria in soil act on the degradation of organic materials into their basic $\left(\mathrm{H}_{2} \mathrm{O}, \mathrm{CO}_{2}\right)$ and secondary materials (alcohol, organic acids, methane and hydrogen). The degradation of materials occurs when the bacteria and fungi are present in sufficient quantities. Fungi are living organisms that are widely spread in different media found in wet and dry soils. They are characterized by the digestion of food externally and not internally within the digestive cavity. Fungi absorb the nutrients into the cells after the completion of the digestion process; these are the release of hydrolyzes dissolve the cells of plant tissues or animal or organic materials that feed on them. Fungi have a remarkable power to break up wood and it eliminates polluting and toxic substances. Some researchers studied fungi, for their use in soil purification and pollution treatment. The proportion of fungi in the soil was $\left(3^{*} 10^{4}\right)$ for PVA and $\left(3.2^{*} 10^{4}\right)$ for PEG. 


\section{3-2-2 Soil Burial Test}

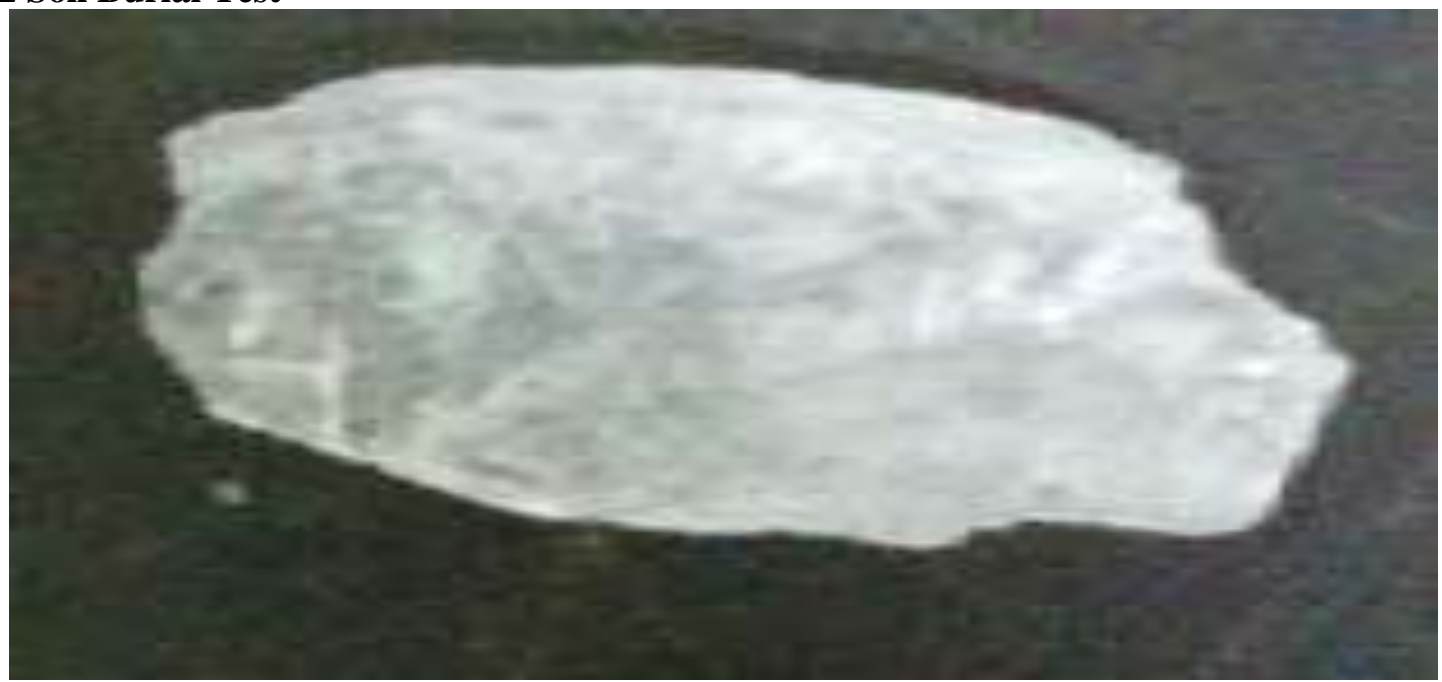

Figure 5- The sample of PEG before being buried.

Figure-5 shows the thick film of PEG before being buried in soil. PEG was observed to have fast decomposition in soil within a very short time of one week. Figure-(6, shows the particles of polymer distributed in the soil matrix. We also observed that the product of decomposition is made of organic materials that have no toxicity. The results of laboratory tests of microorganisms and organic carbon proved that polyethylene glycol has no negative impacts on the soil.
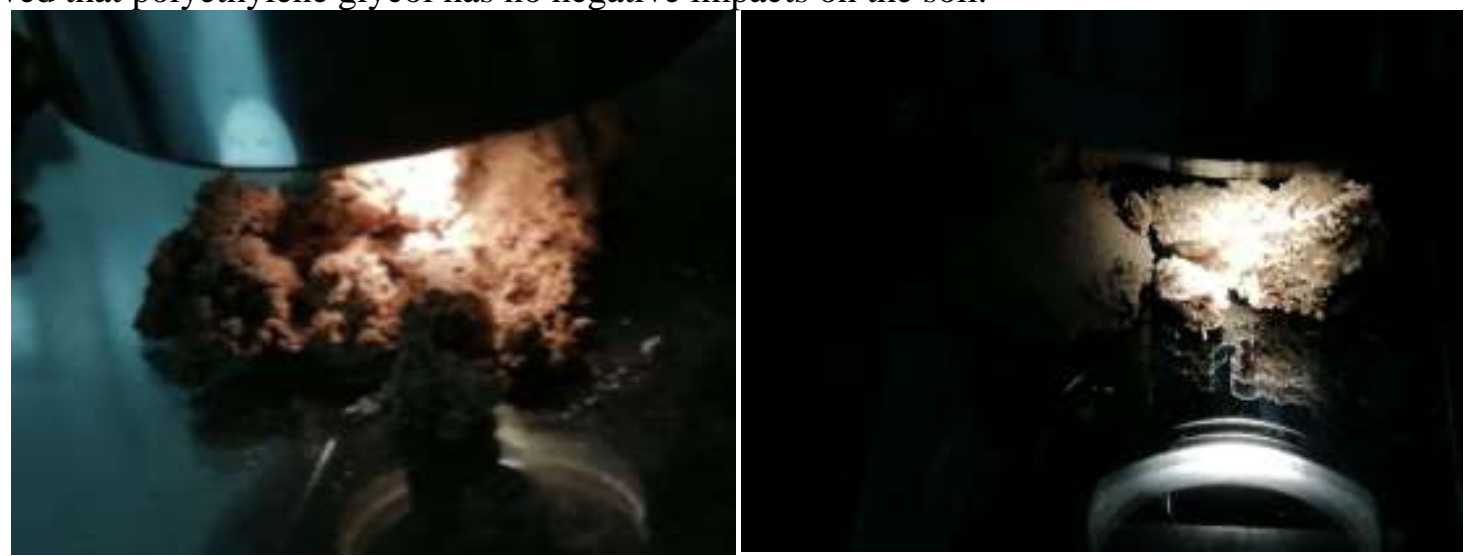

Figure 6- The decomposition of PEG polymer and its distribution within soil particles.

But PVA film needed more time and the weight and thickness loss of the samples was measured every week for 3 months, where the changes in the sample were followed by optical microscope.

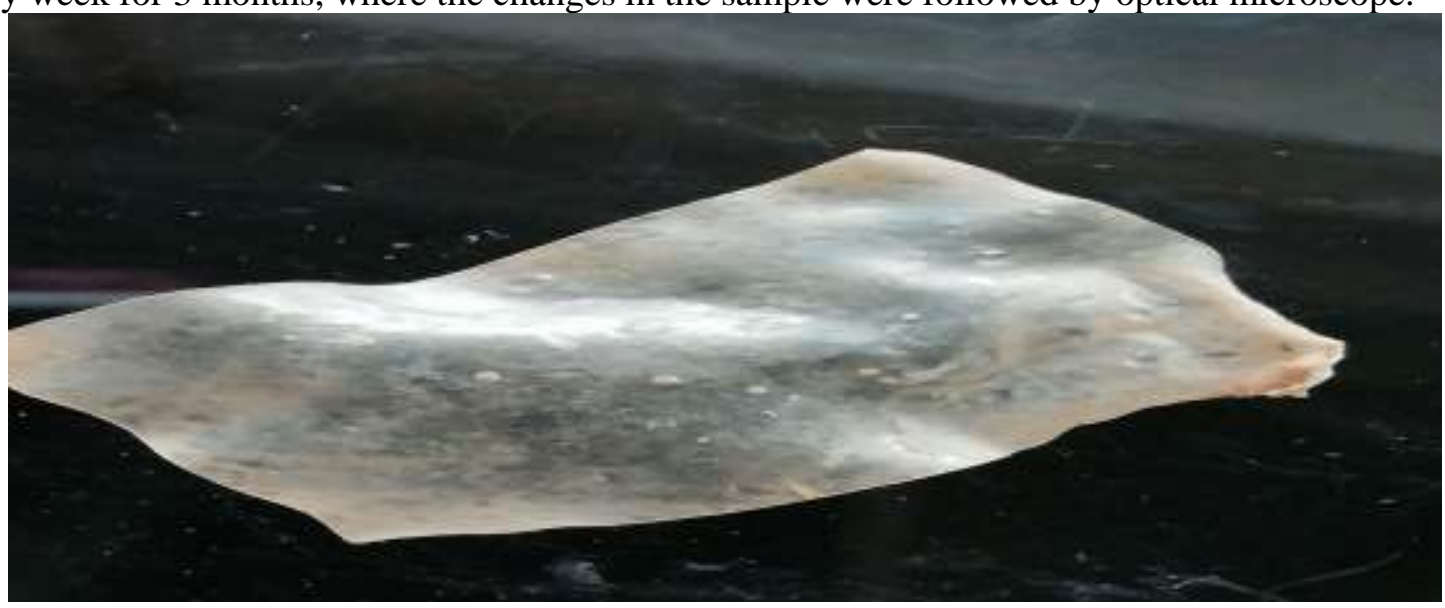

Figure 7- The sample of PVA after one month in soil. 
The results of burying for one month in the soil showed that the sample began to increase its weight in the first week then decreased gradually, depending on the type of material and thickness and depth of the soil. The changes were very simple in the thickness of the thick film and, therefore, it cannot be implied that the polymer began to degrade.

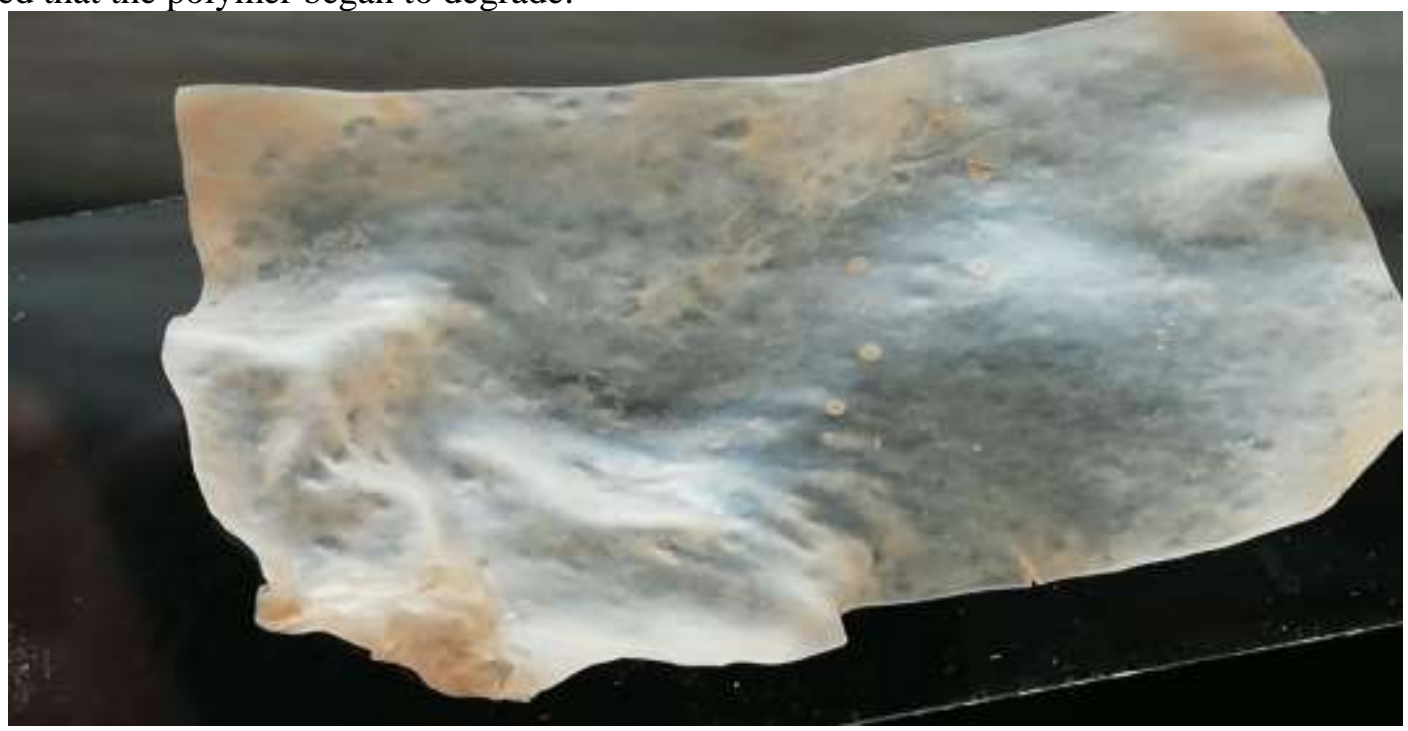

Figure 8- The sample of PVA after two months in soil.

In the second month, some minor holes appeared on the surface of the sample that could be observed through the optical microscope, where the soil granules began permeating through the thick membrane of the polymeric material.

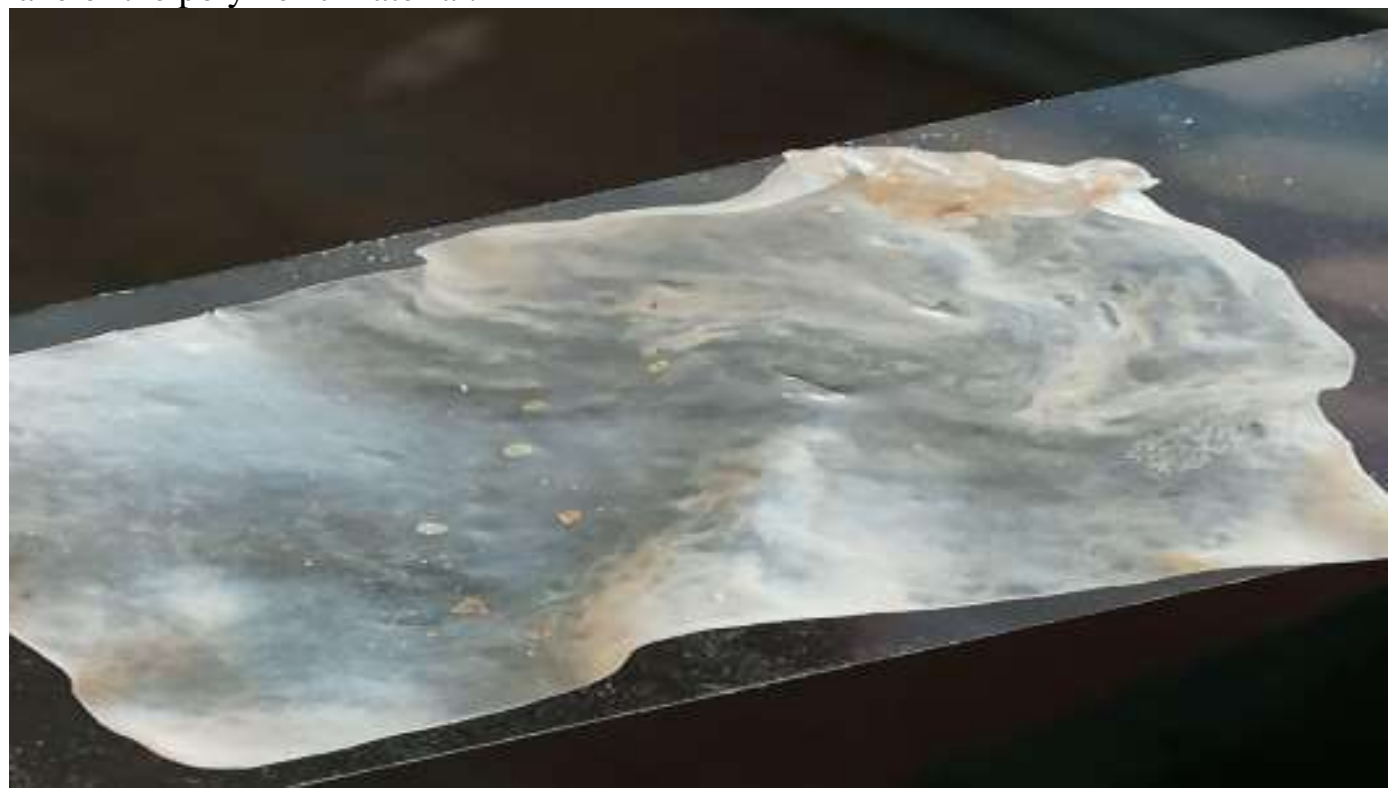

Figure 9- The sample of PVA after three months in soil.

In third month of polymer embedding in soil, we observed deformation in the form of a decrease in weight of the sample from $0.30 \mathrm{~g}$ to $0.26 \mathrm{~g}$. The sample also had many ripples and holes after 3 months of degradation, indicating the partial biodegradation of the polymer. The holes on the surface of the polymer could be observed with the naked eye, along with changes in shape of the sample and the edges which began to shrink It was also easy to see that certain regions were thick whereas others were less in thickness. When examining the sample under optical microscope, we found grains of soil overlapping with the polymer, indicating the interference between the grains of soil with the polymer sample. 
The polymer sample was degraded by loss of structural integrity which renders it advantageous in terms of environmental protection against the waste of plastic materials. Figure-10 shows the weight loss for the biopolymer PVA at different thicknesses $(t=0.46$ and $0.34 \mathrm{~cm})$. It was observed that the sample with lower thicknesses began to decompose faster.

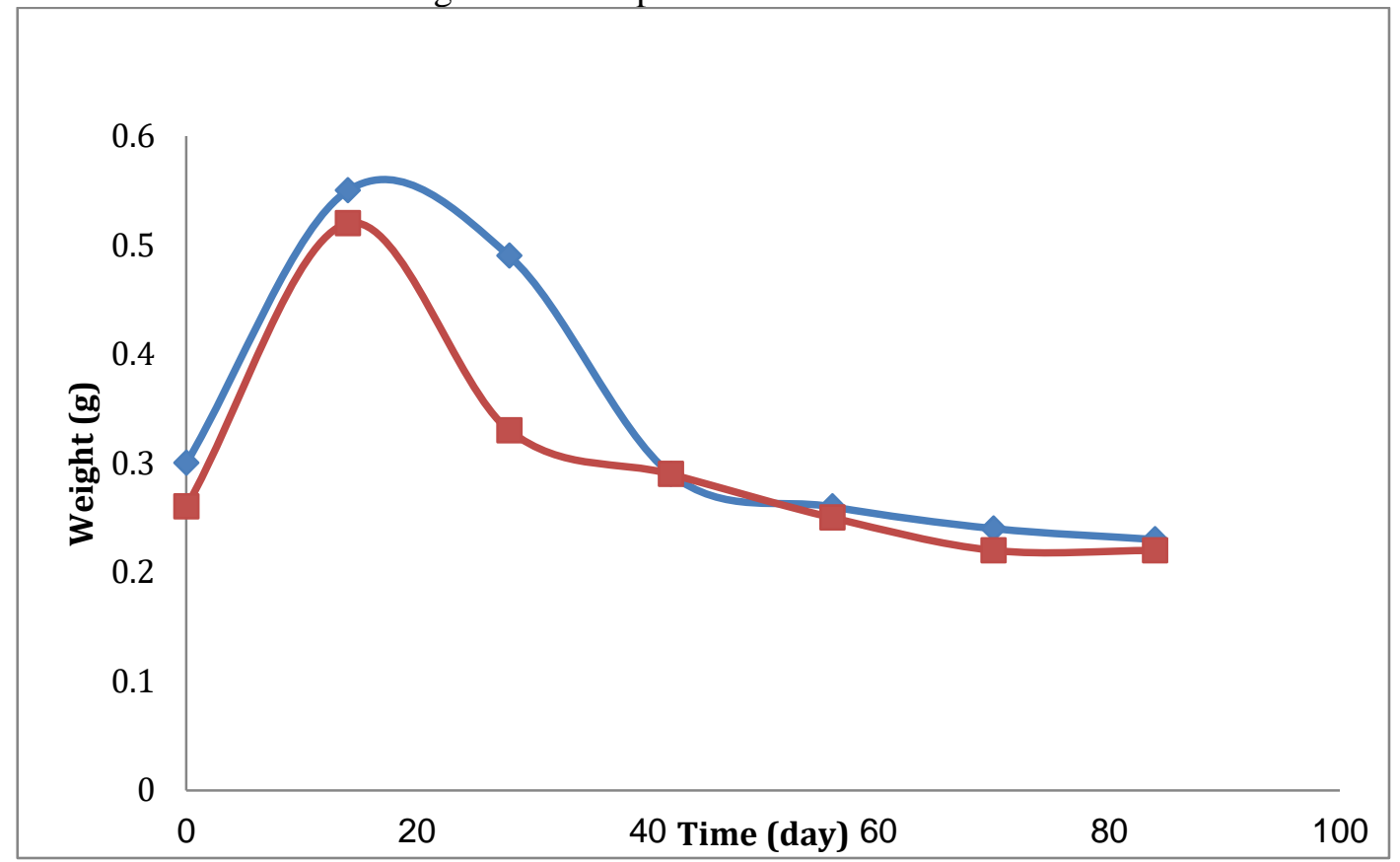

Figure10-The change in weight as a function of burying time

Figure-11 shows the change in the sample thickness as a function of burying time. We noticed that the sample with lower thickness degraded faster, being changed from 0.34 to $0.27 \mathrm{~cm}$.

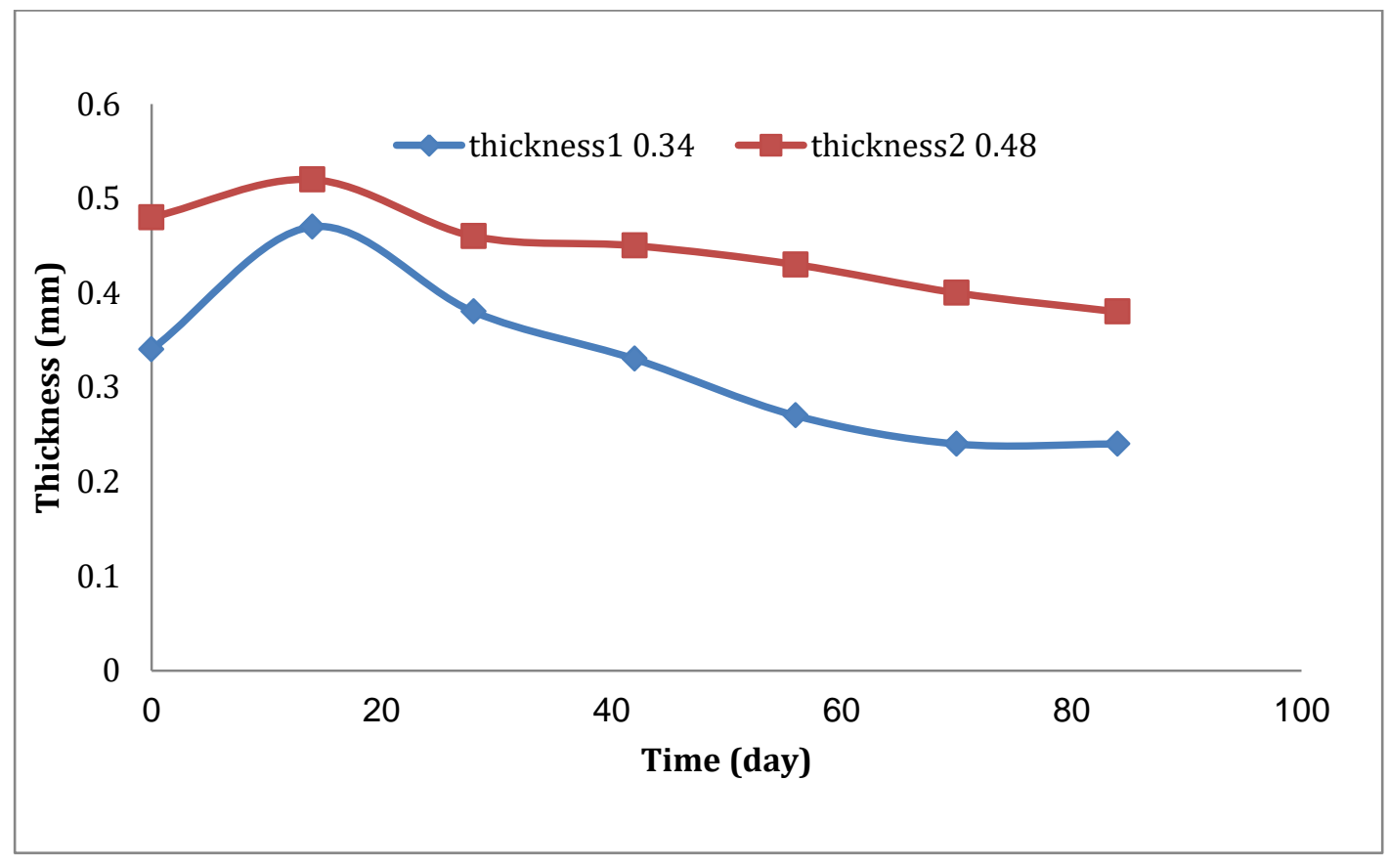

Figure 11-The change of thickness as a function of burying time. 


\section{Conclusions}

The use of bio-degradable polymers in agriculture was shown to help to improve soil properties, increase soil fertility, reduce soil contamination, and increase the use of waste materials to reduce pollution. Polymer films were prepared by the casting method and the micro-organic culture and soil burial tests demonstrated the good bio-degradability of the films. PEG degraded in one week but PVA needed more than 3 months. When the thickness of sample was increased the degradation was decreased, i.e. there was a need for more time. The soil burial test, FT-IR and optical micro scope analyses indicated that the degradation degree of the films was decreased in the following order: PEG film > PVA film.

\section{References}

1. Gowariker, V. R., Viswanathan, N. V. and Shreedhar, J. 2005. Polymer Science, New Age International, New Delhi.

2. Zezin, A.B., Mikheikin, S.V., Rogacheva, V.B., Zansokhova, M.F., Sybachin, A.V., Yaroslavov, A.A. 2015. Polymeric stabilizers for protection of soil and ground against wind and water erosion. Adv. Colloid Interface Sci., 226: 17-23.

3. Acín-Carrera, M., José Marques, M., Carral, P., Álvarez, A.M., López, C., Martín-López, B. and González, J.A. 2013. Impacts of land-use intensity on soil organic carbon content, soil structure and water-holding capacity. Soil Use Manag., 29: 547-556.

4. Ekebafe, L.O. Ogbeifun, and D.E. Okieimen, F.E. 2011 . Polymer Application in Agriculture, 23(2): Jun 81-89.

5. Keesstra, S.G. Leeuw, J.Okx, J. Cleen, M. and Visser, S. 2018. Soil-related Sustainable Development Goals: Four .concepts to make land degradation neutrality and restoration work. Land, 7: 133.

6. Nutullah, Ö. Elif Öztürk, Ö. Tebessüm K. D. İmanverdi, E. 2015. "Effects of organic and inorganic amendments on soil erodibility", Eurasian J Soil Sci, 4(4) $266-271$.

7. EObasi F.N. Eze I.O, Nwanonenyi S.C, Arukalam I.O. and Uzoma P.C. 2013. "Effect of soil burial on properties of polypropylene (PP) / plasticized Potato starch (PPS) blends" ,International and Journal of Engineering and Science (IJES), , 2(8): 14-18.

8. Citation: Ontl, T. A. and Schulte, L. A. 2012. Soil Carbon Storage. Nature Education Knowledge 3(10): 35, Research: Arid areas absorb unexpected amounts of carbon April 6, 2014.

9. Ames, I.A. and Lisa A. S. 2012. Soil Carbon Storage, , Iowa State University,Ames,IA) () Nature Education by Todd A. Ontl.

10. Matejkova, S. and Simon, T. 2012. "Application of FTIR spectroscopy for evaluation of hydrophobic/ hydeophilic organic components in arable soil, Plant Soil Envron, 58(4): 192-195.

11. ECOTERRA, 2014. Polyvinyl alcohol and starch blends: properties and biodegradation behavior, journal of environmental research and protection, 11(1).

12. Anji Reddy P. and Ranveer K. 2011. "Impedance spectroscopy and FTIR studies of PEG based polymer electrolytes", E-Journal of chemictry, 8(1): 347-353. 